EL MUHASABA: Jurnal Akuntansi (e-Journal)

Volume 12 , No. 1, Tahun 2021

P ISSN: 2086-1249 ; E ISSN: 2442-8922

\title{
FAKTOR PENGARUH RASIO KEUANGAN TERHADAP HARGA SAHAM PERUSAHAAN JAKARTA ISLAMIC INDEX (JII)
}

\author{
Nadiah Ayu Salsabila 1, Titis Miranti 2 \\ Universitas Islam Negeri Maulana Malik Ibrahim Malang1,2 \\ Jalan Gajayana No. 50 Malang, 65144, Indonesia \\ e-mail: titis@uin-malang.ac.id 2
}

\begin{abstract}
Jakarta Islamic Index is a stock index in the IDX that can use as an alternative In Islamic investment. In choosing an investment object in Islamic stocks, it necessary to pay attention to the financial ratios and stock prices of companies. The purpose of this study was to determine the effect of financial ratios on stock prices on companies listed on the Jakarta Islamic Index (JII). The type of this research is quantitative. The population of 56 companies registered on the Jakarta Islamic Index (JII) for the 2012-2018 period with a sample of 11 companies. The analysis model use panel data regression using Eviews software. The type of data uses secondary data accessed through the Indonesia Stock Exchange (IDX) website. The results showed that earning per share variable has a significant effect on stock prices. While the current ratio, debt to equity ratio, total assets turnover and net profit margin variables have no significant impact on stock prices. Simultaneously variables of current ratio, debt to equity ratio, total assets turnover, net profit margin and earning per share have significant effects on stock prices. The contribution of this research can use as a reference for companies to pay attention to financial ratios that affect stock prices.
\end{abstract}

Keywords: Jakarta Islamic Index (JII); Financial Ratio; Stock Price

\section{Abstrak}

Jakarta Islamic Index merupakan indeks saham yang dapat dijadikan alternatif dalam berinvestasi syariah. Dalam memilih memilih objek investasi pada saham syariah, perlu memperatikan rasio keuangan dan harga saham perusahaan. Tujuan penelitian untuk mengetahui pengaruh rasio keuangan terhadap harga saham pada perusahaan yang terdaftar di Jakarta Islamic Index (JII). Adapun jenis penelitian ini adalah kuantitatif. Populasi sebanyak 56 perusahaan yang terdaftar pada Jakarta Islamic Index (JII) periode 2012-2018 dengan sampel berjumlah 11 perusahaan. Model analisis yang digunakan yaitu regresi data panel. Data yang digunakan merupakan data sekunder yang diakses melalui website Bursa Efek Indonesia (BEI). Hasil penelitian menunjukkan secara parsial variabel earning per share berpengaruh signifikan terhadap harga saham. Sedangkan variabel current ratio, debt to equity ratio, total assets turnover, dan net profit margin tidak berpengaruh signifikan terhadap harga saham. Secara simultan variabel current ratio, debt to equity ratio, total assets turnover, net profit margin, dan earning per share berpengaruh signifikan terhadap harga saham. Berdasarka penelitian ini maka pihak investor harus memperhatikan nilai variabel earning per share sebagai salah satu kriteria dalam melakukan investasi.

Kata kunci: Jakarta Islamic Index (JII); Rasio Keuangan; Harga Saham 
Nadiah Ayu Salsabila, Titis Miranti : Faktor Pengaruh Rasio Keuangan Terhadap Harga Saham Perusahaan Jakarta Islamic Index (JII)

\section{PENDAHULUAN}

Pasar modal mempunyai peran penting bagi perkembangan perekonomian di Indonesia. Hal tersebut dikarenakan pasar modal memiliki fungsi utama yakni sebagai fasilitas untuk investasi bagi pemilik modal dan juga sarana untuk mendapatkan dana bagi investor. Adapun pihak yang menyediakan fasilitas bagi pasar modal Indonesia yang biasa dikenal dengan nama Bursa Efek Indonesia (BEI). Metode yang dapat dilakukan untuk melihat kinerja di suatu perusahaan atau lembaga yang masih terdaftar di pasar modal satunya berdasarkan indeks saham. Selain saham konvensional, BEI menyediakan sarana investasi untuk semua penduduk beragama islam yang ingin melakukan investasi dengan tetap menerapkan prinsip-prinsip keislaman dan syariah. BEI mencatat bahwa di Indonesia terdapat beberapa indeks saham antara lain Jakarta Islamic Index70 (JII70), Indeks Saham Syariah Indonesia (ISSI) dan Jakarta Islamic Index (JII).

Beberapa kajian yang menarik untuk diteliti kembali pada pasar modal antara lain, terdapat kenaikan jumlah pada saham syariah yang terdaftar dalam Daftar Efek Syariah (DES) pada tahun 2012 sampai dengan tahun 2018. Berdasarkan Gambar 1 dapat diketahui bahwa jumlah saham syariah yang terdaftar dalam DES dari tahun 2012-2016 periode pertama mengalami kenaian dan penurunan. Berikut merupakan tampilan grafik jumlah saham syariah yang masuk di DES.

Penelitian ini menggunakan objek penelitian pada perusahaan atau sahamsaham yang terdaftar di Jakarta Islamic Index (JII). Keberadaan JII merupakan alternatif bagi masyarakat muslim yang ingin berinvestasi di pasar modal yang sesuai dengan syariat agama. Hal tersebut, disebabkan JII telah melakukan proses screening terhadap saham-saham yang listing pada JII. Proses screening pada saham yang listing di JII dilakukan oleh Otoritas Jasa Keuangan (OJK) dan Dewan Syariah Nasional Majelis Ulama Indonesia (DSN-MUI). Adapun saham yang terdaftar di JII merupakan 30 saham yang paling likuid pada setiap periode (idx.co.id). Lebih dari itu bahwa, saham yang masih beredar/ terdaftar pada JII termasuk saham syariah unggulan (Yuliawati \& Darmawan, 2019).

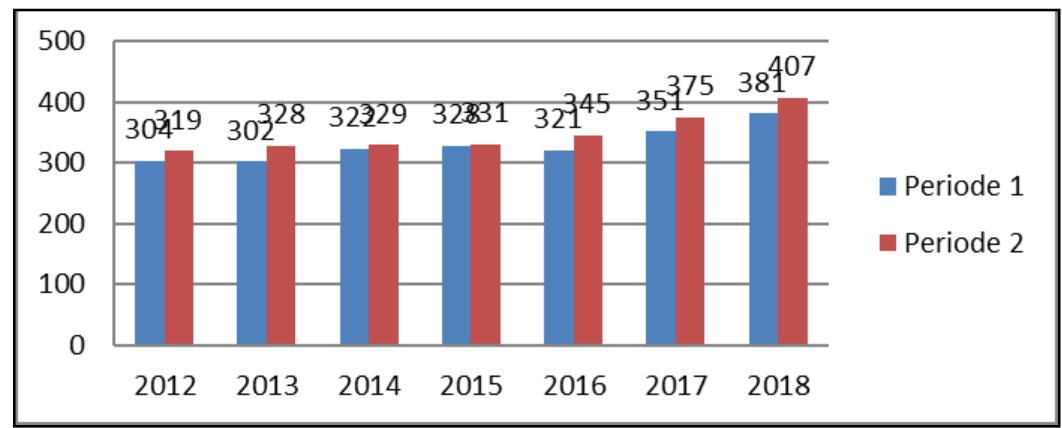

Gambar 1. Jumlah Saham Syariah dalam DES Sumber: Bursa Efek Indonesia, 2019 
Nadiah Ayu Salsabila, Titis Miranti : Faktor Pengaruh Rasio Keuangan Terhadap Harga Saham Perusahaan Jakarta Islamic Index (JII)

Penelitian yang dilakukan oleh Sartika (2017) menyatakan bahwa Indeks Harga Saham Gabungan (IHSG) lenih mengalami ketodakstabilan kondisi jika dibandingkan dengan JII atau harga saham syariah pada masa krisis global. Penelitian lain yang membahas terkait hubungan rasio keuangan terhadap harga saham antara lain dilakukan oleh (Putriyandari, 2018), (Salsabila, 2020), (Cahya et al., 2019). Kondisi demikian dikarenakan investasi pada saham JII merupakan investasi jangka panjang dan tidak tercampur unsur ribawi. Selain itu, investasi pada indeks saham syariah tidak bertujuan untuk spekulasi. Hal tersebut merupakan kelebihan JII dibandingakan dengan IHSG.

Dalam dunia investasi, rasio keuangan memiliki peranan penting dalam melakukan analisis fundametal. Melalui rasio keuangan, investor atau pihak yang memiliki kepentingan kepada perusahaan dapat menilai kinerja perusahaan tersebut. Berdasarkan kinerja perusahaan, investor dapat mengambil keputusan untuk berinvestasi pada perusahaan yang dituju. Selain rasio keuangan, harga saham juga menjadi faktor penting apabila hendak memutuskan berinvestasi pada pasar modal. Pada kondisi umum, Harga saham menggambarkan nilai-nilai dari sebuah perusahaan dimata masyarakat dan khususnya pada investor (Samsuar \& Akramunnas, 2017).

Rasio keuangan terdiri dari beberapa ukuran, diantaranya adalah rasio likuiditas, rasio solvabilitas, rasio profitabilitas, rasio aktivitas, dan rasio pasar. Pada penelitian ini rasio likuiditas ditunjukkan dengan nilai current ratio (CR). Bagherzadeh, dkk. (2013) menyatakan bahwa CR tidka berpengaruh signifikan terhadap harga saham. Sedangkan, Hidayat \& Topowijono (2018) menyatakan sebaliknya. CR mempunyai pengaruh yang signifikan terhadap harga saham. Nilai debt to equity ratio (DER) merupakan rasio yang digunakan untuk mengetahui setiap rupiah modal perusahaan yang dijadikan untuk jaminan utang (Kasmir, 2015). Utami dan Darmawan (2019) dalam penelitiannya menyamoaikan bahwa nilai DER mempunyai pengaruh yang negatif terhadap harga saham. Hal ini didukung oleh Savitri (2016) yang menyatakan bahwa DER berpengaruh signifikan terhadap harga saham. Rasio aktivitas diaproksimasikan pada nilai total asset turnover (TATO). Hasil pengamatan yang dikerjakan oleh Putra, dkk. (2013) pada perusahaan BUMN (Non-Bank) memeperlihatkan bahwa TATO memiliki pengaruh yang signifikan terhadap harga saham industri manufaktur food and beverage. Akan tetapi Asmirantho dan Kusumah (2017) menunjukkan bahwa TATO tidak berpengaruh terhadap harga saham. Variabel net profit margin (NPM) digunakan sebagai rasio profitabilitas. Putriyandari (2018) menyatakan bahwa nilai NPM secara parsial berpengaruh signifikan terhadap harga saham. Namun, penelitian yang dikerjakan oleh Faleria, dkk., (2017) pada tahun 2013-2016 menunjukkan bahwa NPM tidak berpengaruh terhadap harga saham. Pada rasio pasar diaproksimasikan denga nilai earning per share (EPS). Talamati \& Pangemanan (2015) pada perusahaan perbankan yang termasuk dalam BEI menunjukkan bahwa EPS memiliki pengaruh positif 
Nadiah Ayu Salsabila, Titis Miranti : Faktor Pengaruh Rasio Keuangan Terhadap Harga Saham Perusahaan Jakarta Islamic Index (JII)

yang kuat terhadap harga saham. Akan tetapi, Rahmadewi \& Abundanti (2018) menyatakan bahwa EPS tidak berpengaruh secara signifikan terhadap harga saham.

Berdasarkan fenomena tersebut, maka peneliti berusaha untuk mengembangan penelitian terkait dengan rasio keuangan dan harga saham pada perusahaan yang terdaftar di JII. Jumlah tahun yang digunakan dalam penelitian ini yaitu pada tahun 2012-2018. Sehingga tujuan dari penelitian ini yaitu guna menguji dampak rasio keuangan terhadap harga saham pada perusahaan JII. Hal yang menjadi pembeda penelitian ini terhadap penelitian yang dilakukan oleh peneliti sebelumnya adalah pada penelitian ini rasio keungan yang digunakan meliputi rasio pasar, rasio profitabilitas, rasio likuiditas, rasio solvabilitas dan rasio aktivitas. Teknis analisis yang digunaan pada penenlitian ini yaitu regresi data panel. Berdasarkan uraian yang telah dipaparkan, maka dilakukan penelitian dengan tema faktor-faktor yang mempengaruhi rasio keuangan terhadap harga saham pada perusahaan Jakarta Islamic Index (JII).

\section{KAJIAN PUSTAKA}

\section{Rasio Keuangan}

Analisis rasio keuangan merupakan upaya dalam melakukan perbandingan suatu nilai-nilai yang terdapat pada sebuah laporan keuangan melalui pembagian satu angka terhadap angka lainnya (Kasmir, 2015). Berdasarkan informasi yang terdapat di rasio keuangan, maka aspek-aspek yang merasa penting pada perusahaan dapat melihat kinerja perusahaan berdasarkan periode yang dibutuhkan. Adapun rasio keuangan yang digunakan perusahaan yaitu rasio pasar, rasio solvabilitas, rasio profitabilitas rasio aktivitas, dan juga rasio likuiditas.

Perusahaan mempunyai suatu nilai ukur yang menunjukkan kemampuan perusahaan dalam memenuhi kewajiban jangka pendeknya. Ukuran tersebut disebut sebagai rasio Likuiditas (Hery, 2016). Pada pengkajian saat ini, Current ratio (CR) mewakili jenis rasio likuiditas yang digunakan. Nilai $C R$ dapat mengukur kemampuan perusahaan untuk membayarkan/melunasi hutang dengan memanfaatkan aktiva lancar yang dimiliki perusahaan (Sudana, 2015).

Rasio solvabilitas disebut juga sebagai rasio leverage yaitu suatau rasio / ukuran perusahaan yang biasa dimanfaatkan guna mengetahi seberapa besar asset perusahaan yang dibiayai oleh hutang perusahaan. Hery (2016) menyatakan dalam penelitiannya bahwa salah satu rasio solvabilitas yang dapat digunakan dalam penelitian adalah nilai Debt to equity ratio (DER). Nilai DER dapat mengitung kinerja total hutang terhadap tptal asset.

Rasio keuangan yang dimanfaatkan guna menilai efektivitas suatu perusahaan dalam menggunakan semua asset yang dipunyainya. Rasio aktivitas juga dapat digunakan untuk menilai efisiensi perusahaan dalam memakai sumber daya yang dimiliki (Hery, 2016). Pada kajian ini variabel Total assets 
Nadiah Ayu Salsabila, Titis Miranti : Faktor Pengaruh Rasio Keuangan Terhadap Harga Saham Perusahaan Jakarta Islamic Index (JII)

turnover (TATO) digunakan untuk mewakili jenis rasio aktivitas. Nilai TATO juga dapat mengukur efisiensi pemanfaatan seluruh aktiva dalam menghasilkan penjualan (Sudana, 2015), (Sartika, 2017).

Rasio profitabilitas ialah salah satu rasio yang dapat dimanfaatkan untuk menilai kapabilitas suatu perusahaan dalam memperoleh laba dari aktivitas kondisi normal suatu bisnis (Hery, 2016). Net profit margin (NPM) dimanfaatkan sebagai salah satu ukuran yang mewakili rasio profitabilitas. NPM merupakan nilai perbandingan antara keuntungan setelah bunga dan pajak terhadap seluruh penjualannya (Kasmir, 2015).

Rasio yang dimanfaatkan untuk mendapatkan nilai estimasi intrinsik suatu perusahaan atau besaran saham disebut sebagai rasio pasar. Dalam kajian ini rasio pasar yang dugunakan adalah nilai earning per share (EPS). Nilai EPS dapat menghitung kesuksessan manajemen suatu perusahaan dalam memberikan laba untuk seluruh pemilik saham biasa. Rasio pasar ini juga digunakan dalam beberpa penelitam seperti yang dilakukan oleh Hery (2016).

\section{Harga Saham}

Harga saham ialah suatu harga atau nilai yang terbentuk dari interaksi pembali dan juga penjual saham dengan mengorientasikan suatu profit/keuntungan perusahaan. Harga saham merupakan cerminan dari nilai perusahaan (Egam et al., 2017). Sehingga, investor perlu memperhatikan pergerakan harga saham pada perusahaan yang menjadi objek investasinya.

\section{Jakarta Islamic Index (JII)}

Jakarta Islamic Index (JII) merupakan salah satu indeks saham syariah yang terdapat di bursa efek indonesia. JII didirikan dalam rangka untuk mencapai suatu tujuan. Tujuannya yaitu sebagai pemandu investor dalam dalam melakukan investasi di pasar modal yang tetap memperhatikan syariah islam (prinsip syariah). Saat ini jumlah saham yang masih terdaftar di JII sebanyak 30 saham syariah.

Adapun tujuan dari JII digunakan untuk memandu investor yang menginginkan berinvestasi di pasar model yang sesuai dengan syariah. Sehinga, JII merupakan sarana yang disediakan oleh Bursa Efek Indonesia untuk investor yang ingin berinvestasi pada surat berharga syariah.

\section{HIPOTESIS}

Hipotesis dalam penelitian ini merujuk pada penelitian-penelitian sebelumnya. Hipotesis penelitian mmenjadi salah satu tahapan yang boleh dilalui untuk dapat mencapai dan melakukan pengambilan keputusan (Sugiyono, 2007). Keputusan pada hipotesis ini akan menentukan kesimpulan penelitian. Berikut merupakan hipotesis yang digunakan dalam penelitian ini antara lain:

Rasio keuangan memiliki peran penting bagi pihak yang berkepentingan terhadap suatu. Adapun fungsi rasio keuangan bagi pihak investor, rasio 
keuangan merupakan informasi yang dapat digunakan untuk melakukan keputusan berinvestasi. Salah satu bentuk investasi dalam suatu perusahaan yaitu saham.

Current ratio merupakan salah satu rasio likuiditas yang digunakan untuk menunjukkan kemampuan perusahaan dalam memenuhi kewajiban jangka pendeknya menggunakan aset lancar. Semakin besar current ratio yang dimiliki oleh perusahaan menunjukkan bahwa semakin besar pula kemampuan perusahaan dalam memenuhi kebutuhan operasionalnya terutama dalam modal kerja. Modal kerja tersebut berperan penting dalam menjaga kinerja perusahaan dan akan berpengaruh terhadap performance harga saham (Wahnida, 2017)

Hipotesis 1 : Terdapat efek signifikan/nyata dari CR terhadap harga saham.

Debt to equity ratio merupakan salah satu rasio solvabilitas yang digunakan untuk menunjukkan kemampuan perusahaan dalam memenuhi seluruh kewajibannya menggunakan modal yang dimiliki. Sehingga naik/turunnya modal perusahaan juga akan berpengaruh pada DER perusahaan. Hal tersebut juga dapat mempengaruhi harga saham perusahaan (Savitri, 2016).

Hipotesis 2 : Terdapat efek signifikan/nyata DER terhadap harga saham.

Total assets turnover merupakan salah satu rasio aktivitas yan digunakan untuk menunjukkan keefektifan penggunaan aktiva perusahaan dalam menghasilkan penjualan. Apabila perusahaan meiliki kemampuan yang baik dalam mengelola aktivanya, hal ini akan meningkatkan keyakinan investor terhadap perusahaan dalam mengelola dananya. Sehingga, hal tersebut juga akan berpenharuh terhadap harga saham di perusahaan tersebut (Putra et al., 2013).

Hipotesis 3 : Terdapat efek signifikan/nyata dari nilai TATO terhadap harga saham.

Net profit margin merupakan rasio yang digunakan untuk menunjukkan kemampuan perusahaan dalam menghasilkan laba melalui penjualannya. Apabila suatu perusahaan dapat menghasilkan laba yang tinggi, akan berpengaruh terhadap return saham. Sehingga saham dari perusahaan tersebut akan banyak diminati oleh investor dan dapat mempengaruhi harga saham perusahaan (Putriyandari, 2018).

Hipotesis 4 : Terdapat efek signifikan/nyata dari nilai NPM terhadap harga saham.

Earning per share merupakan rasio yang digunakan untuk mengukur kemampuan perusahaan dalam memberikan keuntungan bagi pemegang saham. Sehingga apabila perusahaan memiliki tingkat EPS yang tinggi, maka saham perusahaan tersebut akan diminati oleh investor dan dapat berpengruh terhadap harga saham pada perusahaan tersebut (Talamati \& Pangemanan, 2015). 
Nadiah Ayu Salsabila, Titis Miranti : Faktor Pengaruh Rasio Keuangan Terhadap Harga Saham Perusahaan Jakarta Islamic Index (JII)

Hipotesis 5 : Terdapat efek signifikan/nyata dari nilai EPS terhadap harga saham.

\section{METODE}

Jenis penelitian ini merupakan penelitian kuantitatif. Populasi dalam penelitian ini adalah semua jenis perusahaan yang terdaftar pada JII dari tahin 2012 sampai dengan tahun 2018 dengan total perusahaan sebanyak 58 perusahaan. Metode purposive sampling digunakan sebagai teknik pengambilan sampling pada penelitian ini. Kriteria yang digunakan adalah perusahaan tersebut mempublikasikan laporan keuangan tersebut di OJK pada kurun waktu penelitian. Perusahaan yang secara stabil terdaftar pada JII pada periode tahun 2012 sampai dengan tahun 2018 ada 11 perusahaan. Adapun analisis yang digunakan dalam penelitian ini adalah regresi data panel. Dalam pengolahan data, kajian ini menggunakan software Eviews.

\section{HASIL DAN PEMBAHASAN}

\section{Pembentukan Model Regresi Data Panel}

Dalam regresi data panel, terdapat 3 model yang dapat digunakan, yaitu, Common Effect Model (CEM), Fixed Effect Model (FEM) dan Random Effect Model (REM). Model CEM merupakan pendekatan dengan mengombinasikan data cross section dengan data time series. Pada common effect model tidak memperhatikan dimensi waktu maupun individu, sehingga dalam model ini diasumsikan bahwa perilaku data perusahaan sama dalam waktu yang tertentu. Model FEM merupakan model yang perbedaan individu antar perusahaan dapat dilihat dari nilai intersep model. Variabel dummy dibutuhkan untuk melakukan estimasi menggunaka model fixed effect. Metode estimasi/pendekatan tersbut biasanya dikenal dengan metode Least Square Dummy Variable (LSVD). Model REM adalah model panel yang variabel gangguannya memiliki pengaruh antar antar individu dan juga antar waktu. Pada model random effect perbedaan atau selisih antar intersep dapat dilihat dari error terms masing-masing perusahaan.

Dalam pemilihan model data panel, penelitian ini menggunakan uji chow dan uji hausman. Uji Chow diperlukan untuk menentukan pilihan model terbaik antara commn effect model dan fixed effect model. Pemilihan model tersebut dilihat berdasarkan nilai F-statistic atau nilai probabilitasnya. Hipotesis yang digunakan pada uji Chow adalah sebagai berikut:

Hipotesis Nol: Common Effect model lebih baik digunakan apabila nila probabilitas lebih besar dari a $(0,05)$

Hipotesis satu: Fixed effect model lebih baik digunakan apabila nilai probabilitas model lebih lebih kecil a $(0,05)$

Berdasarkan uji chow, didapatkan hasil probabilitas sebesar 0,0000. Hal ini berarti nilai probabilitas < a $(0,05)$. Berdasarkan nilai probabilitas terbut maka model yang sesuai/fit model adalah fixed effect model. 
Nadiah Ayu Salsabila, Titis Miranti : Faktor Pengaruh Rasio Keuangan Terhadap Harga Saham Perusahaan Jakarta Islamic Index (JII)

Uji Hausman merupakan uji yang dimanfaatkan untuk menentukan model terbaik antara random effect model dan fixed effect model. Sama halnya dengan uji chow, uji hausman juga menggunakan nilai F-statistic atau nilai probabilitas sebagai pengambil keputusan. Adapun hipotesis yang digunakan pada uji Hausman adalah:

Hipotesis Nol : Random Effect model lebih baik digunakan jika nilai probabilitas lebih besar dari a $(0,05)$

Hipotesis satu: Fixed effect model lebih baik digunakan jika nilai probabilitas model lebih lebih kecil a $(0,05)$

Berdasarkan uji hausman, didapatkan hasil probabilitas sebesar 0,0000. Hal ini berarti nilai probabilitas < a $(0,05)$. Sehingga, model yang sesuai berdasarkan uji hausman yaitu fixed effect model.

Berdasarkan uji chow dan uji hausman telah didapatkan hasil yang sama, yaitu fixed effect model. Sehingga dalam penelitian ini tidak perlu dilakukan uji langrage multiplier. Sistematika penulisan hasil dan pembahasan harus mengacu pada tujuan dan hipotesis penelitian. Dalam pembahasan diwajibkan untuk mencantumkan rujukan ilmiah sebagai bahan pembanding.

\section{Model Data Panel Terbaik dalam Penelitian}

Tabel 1 menunjukkan hasil dari olah data menggunakan model FEM. Berdasarkan Tabel 1 dapat dilihat bahwa yang memiliki pengaruh signifikan terhadap harga saham yaitu Earning per share (EPS). Hal tersebut dilihat dari besarnya peluanng atau probabilita pada variabel EPS sebesar 0,00. Adapun koefisien EPS sebesar 0,613747. Hal ini berarti apabila faktor selain EPS dianggap tetap, maka 1 satuan kenaikan EPS akan mempengaruhi kenaikan pada harga saham sebesar 0,613 satuan. Berdasarkan hasil regresi pada Tabel 1 diperoleh persamaan regresi data panel sebagai berikut: Harga saham $i, t=5,255+0,00005 \mathrm{CR}_{\mathrm{i}, \mathrm{t}}+0,045 \mathrm{Ln} \mathrm{DER}_{\mathrm{i}, \mathrm{t}}-0,126 \mathrm{TATO}_{\mathrm{i}, \mathrm{t}}+$

$$
0,005 \mathrm{NPM}_{\mathrm{i}, \mathrm{t}}+0,614 \mathrm{LnEPS}_{\mathrm{i}, \mathrm{t}}{ }^{*}+\varepsilon_{\mathrm{i}, \mathrm{t}}
$$

Tabel 1. Hasil Uji Regresi Panel (Fixed Effect Model)

\begin{tabular}{lcccc}
\hline \multicolumn{1}{c}{ Variabel } & Koefisien & Std. Error & T. Statistic & Prob \\
\hline Konstanta & 5,254624 & 0,574180 & 9,151526 & 0,0000 \\
Current ratio (CR) & 0,0000499 & 0,000610 & 0,081716 & 0,9351 \\
Debt to equity ratio (DER) & 0,044817 & 0,047103 & 0,951466 & 0,3451 \\
Total assets turnover (TATO) & $-0,126203$ & 0,105315 & $-1,198336$ & 0,2354 \\
Net profit margin (NPM) & 0,004567 & 0,008201 & 0,556910 & 0,5796 \\
Earning per share (EPS) & 0,613747 & 0,099994 & 6,137836 & 0,0000 \\
\hline
\end{tabular}

\section{Sumber: Data diolah dengan eviews, 2020}

\section{Uji Asumsi Klasik}

Uji asumsi klasik dilakukan setelah model penelitian telah terbentuk. Regresi data panel merupakan pengembangan dari regresi linier berganda dan merupakan bagian dari analisis statistika parametrik. Analisis statistika parametrik mensyaratkan suatu sebaran residu berdistribusi normal, identik/ 
homogen dan independent. Pengujian asumsi normalitas dilakukan untuk melihat apakah rdesual/error yang dihasilkan oleh model mempunyai distribusi normal atau tidak (Basuki \& Yuliadi, 2014). Pada penelitian ini asumsi kenormalan diuji menggunakan nilai Jarque Bera. Apabila nilai Jarque Bera lebih besar dari a $(0,05)$ maka residual model berdistribusi normal. Berdasarkan hasil pada uji normalitas diperoleh besarnya probabilitas Jarque Bera sebesar 0,081. Sehingga dapat dsimpulkan bahwa residual berdistribusi normal.

Multikolinearitas adalah kondisi pada model regresi dimana terdapat hubungan yang linier/searah antar variabel bebas/ variabel independent (Basuki \& Yuliadi, 2014). Adapun hasil output pada uji multikolinearitas seperti yang tertera pada Tabel 2. Nilai VIF pada setiap variabel independen masing-masing kurang dari 10. Sehingga tidak terjadi gejala multikolinearitas.

Tabel 2. Hasil Uji Multikolinearitas

\begin{tabular}{|c|c|}
\hline Variabel & VIF \\
\hline CR & 1,143555 \\
\hline DER & 1,156648 \\
\hline TATO & 1,042293 \\
\hline NPM & 2,062781 \\
\hline EPS & 2,015179 \\
\hline
\end{tabular}

Uji homokedastisitas bermanfaat untuk menguji apakah varians error/residu dalam model regresi mempunyai nilai yang sama atau tidak (Basuki \& Yuliadi, 2014). Hasil uji homokedastitias menununjukkan nilai probabilitas sebesar 0,2221. Nilai probabilitas ini lebih besar dari a $(5 \%)$. Berdasarkan nilai tersebut maka dapat disimpulkan bahwa residu/error model mempunyai varians yang sama atau homogen.

Pengujian autokorelasi dilakukan untuk melihat ada atau tidaknya korelasi dari residual disetiap pengamatan terhadap pengamatan lainnya (Basuki \& Yuliadi, 2014). Berdasarkan hasil uji autokorelasi diperoleh nilai probabilitas pada LM test adalah 0,0863. Nilai probabilitas tersebut berarti bahwa setiap residual pengamatan tidak mengalami autokorelasi. Kondisi ini baik dan memenuhi asumsi klasik.

\section{Uji Hipotesis}

Uji hipotesis ini dilakukan untuk menguji pengaruh parsial setiap vaiabel indepeden dalam penelitian. Dengan demikian maka uji ini disebut juga sebagai uji parsial yaitu bentuk uji hipotesis yang bertujuan untuk melihat adakah pengaruh/hubungan secara signifikan dari setiap variabel bebas/independent terhadap variabel terikat/dependen. Untuk dapat melihat hasil uji parsial maka dibutuhkan nilai t-statistik atau dengan nilai probabilitas dari koefisien setiap variabel bebas. Ketentuan uji $\mathrm{t}$, jika nilai $\mathrm{t}$-statistik lebih besr dari nilai $\mathrm{t}$-tabel atay nilai probabilitas lebih kecil dari 0,05 maka variabel bebas mempunyai pengaruh 
Nadiah Ayu Salsabila, Titis Miranti : Faktor Pengaruh Rasio Keuangan Terhadap Harga Saham Perusahaan Jakarta Islamic Index (JII)

yang signifikan terhadap variabel terikat/dependen. Adapun hasil uji $\mathrm{T}$ pada penelitian ini seperti yang tertera pada Tabel 3.

Tabel 3. Uji Parsial

\begin{tabular}{|c|c|c|}
\hline Variabel & t-Statistic & Prob. \\
\hline CR & 0,081716 & 0,9351 \\
\hline DER & 0,951466 & 0,3451 \\
\hline TATO & $-1,198336$ & 0,2354 \\
\hline NPM & 0,556910 & 0,5796 \\
\hline EPS & 6,137836 & 0,0000 \\
\hline
\end{tabular}

Sumber: Data diolah dengan eviews, 2020

Tabel 3 menunjukkan nilai t-statistic dan juga probabilitasnya untuk setiap variabel independent. Berdasarkan nilai-nilai teresut dapat dikatuhi bahwa variabel CR, DER, TATO dan NPM tidak berpengaruh secara signifikan dan parsial terhadap harga saham. Hal tersebut disimpulkan berdasarkan nilai probabilitas masing-masing nilai yang besarannya menunjjukan nilai lebih a $(0,05)$. Variabel yang secara signifikan mempengaruhi harga saham dalam penelitian ini adalah nilai EPS. Hal ini disimpulkan berdasarkan nilai probabilitas dari EPS yaitu 0,0000 dan lebih kecil dari nilai a $(0,05)$.

\section{Pembahasan}

Berdasarkan uji parsial yang disampaikan pada Tabel 3 menunjukkan bahwa variabel Current ratio tidak berpengaruh signifikan terhadap harga saham. Hasil penelitian ini berbeda dengan teori dikarenakan investor tidak begitu melihat current ratio dalam pengambilan keputusan investasi. Penelitian yang dilakukan oleh (Cholidia, 2017) menyatakan bahwa faktor psikologis investor mengambil peran penting dalam pengambilan keputusan investasi dan tidak menggunakan analisis fundamental dalam pengambilan keputusan investasi. Hasil penelitian ini sesuai dengan penelitian yang dilakukan oleh (Rahmadewi \& Abundanti, 2018) dan (Hidayat \& Topowijono, 2018) yang menyatakan bahwa current ratio tidak berpengaruh signifikan terhadap harga saham pada Perusahaan Otomotif dan Komponen yang terdaftar di Bursa Efek Indonesia periode 2012-2016.

Variabel debt to equity ratio tidak berpengaruh signfikan terhadap harga saham. Hasil penelitian ini berbeda dengan teori dikarenakan perusahaan multinasional lebih banyak menggunakan hutang daripada perusahaan domestik. Adapun hutang tersebut dipergunakan untuk menunjang ativitas perusahaan. Sehingga, perusahaan multinasional akan mendapatkan perlakuan istimewa dari bank karena menghasilkan keuntungan yang lebih banyak. Selain itu, perusahaan multinasional juga memiliki akses yang lebih mudah ke perusahaan internasional untuk memperoleh dana. Berdasarkan hal tersebut, investor tidak terlalu mempertombangkan DER dalam mengambil keputusan investasi (Alifiawan et al., 2019). Hasil ini memiliki kesesuaian dengan kajian yang disampaikan oleh penelitian yang dilakukan oleh Utami dan Darmawan 
Nadiah Ayu Salsabila, Titis Miranti : Faktor Pengaruh Rasio Keuangan Terhadap Harga Saham Perusahaan Jakarta Islamic Index (JII)

(2019). Pada kajian tersebut disampaikan bahwa variabel debt to equity ratio tidak berpengaruh signifikan terhadap harga saham pada perusahaan yang terdaftar di Index Saham Syariah Indonesia (ISSI) pada periode tahun 2012 sampai dengan tahun 2016.

Berdasarkan uji parsial pada Tabel 3 dapat diketahui bahwa total assets turnover tidak berpengaruh signifikan terhadap harga saham. Hasil penelitian ini berbeda dengan teori dikarenakan saat mengambil keputusan berinvestasi, perputaran aset suatu perusahaan tidak terlalu diperhatikan oleh investor. Menurut Weston dan Bringham "inflasi menyebabkan nilai ativa yang dibeli pada waktu lalu menjadi semakin kecil". Sehingga perputaran aktiva pada perusahaan yang membeli aset sebelum inflasi akan lebih baik daripada perusahan yang membeli asset setelah terjadinya inflasi. Adapun kajian ini mempunyai kemiripan dengan penelitian yang dilakukan oleh hasil penelitian ini sesuai dengan penelitian Asmirantho \& Soemantri (2017) yang menyebutkan bahwa nilai total assets turnover tidak mempunyai pengaruh yang nyata pada harga saham perusahaan industry farmasi yang tercatat di Bursa Efek Indonesia (BEI) pada periode 2012 sampai 2016.

Berdasarkan uji parsial pada Tabel 3 menunjukkan bahwa net profit margin tidak berpengaruh signifikan terhadap harga saham. Hasil penelitian ini berbeda dengan teori dikarenakan rasio NPM tidak dapat diketahui secara pasti apakah laba tersebut didapatan berdasarkan keuntungan operasional atau berdasarkan keuntungan lainnya. Hasil kajian tersebut mempunyai kesesuaian dengan hasil kajian yang dilakukan oleh Faleria, dkk (2017). Kajian tersebut menyatakan bahwa nilai net profit margin tidak mempunyai efek atau pengaruh yang nyata terhadap harga saham pada Perusahaan Food and Beverages yang terdaftar dalam Bursa Efek Indonesia (BEI) pada periode tahun 2013 sampai dengan tahun 2016.

Earning per share berpengaru signifikan terhadap harga saham. Adapun hasil tersebut dapat dilihat melalui Tabel 3. Hal ini menandakan dalam melakukan keputusan investasi, investor mempertimbangkan tingkat EPS suatu perusahaan. Semakin banyak tingkat EPS yang diberikan perusahaan kepada investor, semakin diminati saham pada perusahaan tersebut oleh investor. Hasil kajian ini memiliki kesamaan dengan kajian yang dilakukan oleh Putriyandari (2018). Pada penelitian tersebut menyebutkan bahwa nilai earning per share memilki pengaruh yang nyata/signifikan terhadap harga saham pada perusahan manufaktur pada sektor industry dan barang konsumsi yang listing di BEI. Hasil penelitian ini tidak sejalan dengan penelitian yang dilakukan oleh Rahmadewi \& Abundanti (2018) menunjukkan bahwa EPS tidak berpengaruh signifikan terhadap harga saham. 
Nadiah Ayu Salsabila, Titis Miranti : Faktor Pengaruh Rasio Keuangan Terhadap Harga Saham Perusahaan Jakarta Islamic Index (JII)

\section{KESIMPULAN}

Hasil pengujian regresi data panel menunjukkan beberapa hal. Pertama, Secara simultan variabel independent Debt to Equity Ratio (DER), Total Assets Turnover (TATO), Net Profit Margin (NPM), dan Current Ratio (CR), dan Earning Per Share (EPS) berpengaruh signifikan terhadap harga saham. Pengaruh simultan yang diberikan oleh variabel independent terhadap variable dependen (harga saham) tidak menunjukkan bahwa persamaan regresi data panel tersebut layak digunakan untuk membuat suatu model dalam memprediksi harga saham di tahun tertentu. Variabel bebas/independen yang secara signifikan berpengaruh terhadap harga saham yaitu nilai Earning Per Share (EPS). Empat variabel independent lainnya yang digunakan dalam penelitian ini dan tidak mempunyai pengaruh yang signifikan terhadap harga saham antara laian vaibael Debt to Equity Ratio (DER), Total Assets Turnover (TATO), Net Profit Margin (NPM), dan Current Ratio (CR).

\section{DAFTAR PUSTAKA}

Alifiawan, M. M., Ramadhan, A. M., \& Radianto, D. O. (2019). Pengaruh Fundamental dan Makro Ekonomi Terhadap Harga Saham Perusahaan Multi Nasional (Studi Kasus Perusahaan Industri Dasar dan Kimia Tahun 2016-2017). Jurnal Ilmiah Tata Sejuta STIA Mataram, 5(1), 13-27.

Asmirantho, E., \& Somantri, O. K. (2017). The Effect of Financial Performance on Stock Price at Pharmaceutical Sub-Sector Company Listed in Indonesia Stock Exchange. JIAFE (Jurnal Ilmiah Akuntansi Fakultas Ekonomi), 3(2), 94107.

Basuki, A. T., \& Yuliadi, I. (2014). Electronic Data Processing. Yogyakarta: Danisa Media.

Cahya, B. T., Vitriani, E., \& Andriani, A. (2019). Analisis Harga Saham Ditinjau dari Rasio Keuangan Perusahaan yang Listing di Jakarta Islamic Index (JII) Periode 2015-2017. AKTSAR: Jurnal Akuntansi Syariah, 2(2), 265-282.

Cholidia, R. (2017). Perilaku Investor dalam Pengambilan Keputusan Investasi di Pasar Modal (Studi Kasus pada Investor Saham Individu di Bandar Lampung).

Egam, G. E., Ilat, V., \& Pangerapan, S. (2017). Pengaruh Return on Asset (ROA), Return on Equity (ROE), Net Profit Margin (NPM), dan Earning Per Share (EPS) terhadap Harga Saham Perusahaan yang Tergabung dalam Indeks LQ45 di Bursa Efek Indonesia Periode Tahun 2013-2015. Jurnal EMBA: Jurnal Riset Ekonomi, Manajemen, Bisnis Dan Akuntansi, 5(1).

Faleria, R. E., Lambey, L., \& Walandouw, S. K. (2017). Pengaruh Current Ratio, Net Profit Margin Dan Earning Per Share Terhadap Harga Saham Di Bursa Efek Indonesia (Studi Kasus Pada Sub Sektor Food And Beverages). GOING CONCERN: JURNAL RISET AKUNTANSI, 12(2). 
Nadiah Ayu Salsabila, Titis Miranti : Faktor Pengaruh Rasio Keuangan Terhadap Harga Saham Perusahaan Jakarta Islamic Index (JII)

Hery. (2016). Analisis Laporan Keuangan. Grasindo.

Hidayat, D., \& Topowijono, T. (2018). PENGARUH KINERJA KEUANGAN TERHADAP HARGA SAHAM (Studi Pada Perusahaan Pertambangan Subsektor Pertambangan Minyak Dan Gas Bumi Yang Terdaftar Dibursa Efek Indonesia Periode 2013-2016). Jurnal Administrasi Bisnis, 62(1), 36-44.

Kasmir. (2015). Analisis Laporan Keuangan. Raja Grafindo Persada.

Novitasari, P., \& Herlambang, L. (2015). Pengaruh current ratio, total assets turnover, debt to equity ratio, dan return on equity terhadap harga saham pada perusahaan yang terdaftar di jii periode 2009-2013. Jurnal Ekonomi Syariah Teori Dan Terapan, 2(4).

Putra, A. C., Saryadai \& Wahyu H. (2013). Pengaruh Kinerja Keuangan Terhadap Harga Saham pada Perusahaan BUMN (Non-Bank) yang Terdaftar di Bursa Efek Indonesia. Jurnal Ilmu Administrasi Bisnis. 3(1). 178-186.

Putriyandari, R. (2018). Analisis Tingkat Harga Saham Perusahaan Manufaktur Sektor Industri Barang Konsumsi. Kajian Akuntansi, 19(2), 169-178.

Rahmadewi, P. W., \& Abundanti, N. (2018). Pengaruh EPS, PER, CR dan ROE terhadap harga saham di Bursa Efek Indonesia. E-Jurnal Manajemen Universitas Udayana, 7(4).

Salsabila, N. A. (2020). Determinan financial ratio terhadap harga saham pada perusahaan Jakarta Islamic Index (JII) Tahun 2012-2018 [PhD Thesis]. Universitas Islam Negeri Maulana Malik Ibrahim.

Samsuar, T., \& Akramunnas, A. (2017). Pengaruh Faktor Fundamental dan Teknikal terhadap Harga Saham Industri Perhotelan yang Terdaftar di Bursa Efek Indonesia. Al-Mashrafiyah: Jurnal Ekonomi, Keuangan, Dan Perbankan Syariah, 1(1).

Sartika, U. (2017). Pengaruh Inflasi, Tingkat Suku Bunga, Kurs, Harga Minyak Dunia dan Harga Emas Dunia Terhadap IHSG dan JII di Bursa Efek Indonesia. BALANCE: JURNAL AKUNTANSI DAN BISNIS, 2(2), 285-294.

Savitri, L. A. 2016. Pengaruh Leverage, Price Earning, Dividen Payout Ratio terhadap Harga Saham pada Perusahaan Otomotif. Jurnal Ilmu Riset Manajemen, 5(7).

Sudana, I. M. (2015). Manajemen Keuangan Perusahaan Teori dan Praktik Edisi 2. Jakarta: Erlangga.

Sugiyono, M. (2007). Penelitian Bisnis. Bandung: Alfabeta. 
Nadiah Ayu Salsabila, Titis Miranti : Faktor Pengaruh Rasio Keuangan Terhadap Harga Saham Perusahaan Jakarta Islamic Index (JII)

Talamati, M. R., \& Pangemanan, S., S. (2015). The Effect of Earnings Per Share (EPS) \& Return On Equity (ROE) on Stock Price of Bangking Company Listed in Indonesia Stock Exchange (IDX) 2010-2014. Jurnal EMBA. 3(2).

Utami, M. R., \& Darmawan, A. (2019). Effect of DER, ROA, ROE, EPS and MVA on stock prices in Sharia Indonesian stock index. Journal of Applied Accounting and Taxation, 4(1), 15-22.

Wahnida, Selvia. (2017). Pengaruh Current Ratio (CR), Debt to Asset Ratio (DAR) dan Return On Equity (ROE) Terhadap Harga Saham Perusahaan pada Sektor Pertanian dalam Kelompok ISSI. Skripsi. Universitas Islam Negeri Raden Fatah.

Yuliawati, Y., \& Darmawan, D. (2019). Rasio Keuangan dan Pengaruhnya Terhadap Harga Saham Syariah dengan Price Earning Ratio Sebagai Variabel Moderasi. Al-Tijary, 4(2), 109-124.

www.idx.co.id, Diakses pada tanggal 4 November 2019. 